\title{
In Vitro Sex Steroid Metabolism in Red Spotted Grouper, Epinephelus akaara during Oocyte Maturation
}

\author{
In Joon Hwang ${ }^{1}$ and ${ }^{\dagger}$ Hea Ja Baek ${ }^{2}$ \\ ${ }^{1}$ Inland Fisheries Research Institute, National Institute of Fisheries Science, Gapyeong 12453, Korea \\ ${ }^{2}$ Department of Marine Biology, Pukyong National University, Busan 48513, Korea
}

Received: March 1, 2021

Revised: April 9, 2021

Accepted: May 11, 2021

${ }^{\dagger}$ Corresponding author

Hea Ja Baek

Department of Marine Biology, Pukyong National University, Busan 48513, Korea.

Tel: +82-51-629-5924

E-mail: hjbaek@pknu.ac.kr

Copyright $\odot 2021$ The Korean Society of Developmental Biology.

This is an Open Access article distributed under the terms of the Creative Commons Attribution Non-Commercial License (http://creativecommons.org/licenses/ by-nc/4.0/) which permits unrestricted non-commercial use, distribution, and reproduction in any medium, provided the original work is properly cited.

ORCID

In Joon Hwang

https://orcid.org/0000-0001-5740-3925

Hea Ja Baek

https://orcid.org/0000-0002-4578-5919

Conflict of interests

The authors declare no potential conflict of interest.

\section{Acknowledgements}

This study was supported by a Research Grant of Pukyong National University (2019).

Authors' contributions Conceptualization: Baek HJ Data curation: Hwang IJ Formal analysis: Hwang IJ, Baek HJ

Methodology: Baek HJ

Software: Hwang IJ

Validation: Hwang IJ, Baek HJ

Investigation: Hwang IJ, Baek HJ

Writing-original draft: Hwang IJ

Writing-review \& editing: Hwang IJ, Baek HJ

\section{Abstract}

We studied steroid metabolites produced from red-spotted grouper ovarian follicles during maturation. Oocytes with 350-500 $\mu \mathrm{m}$ diameter were in vitro incubated in the presence of $\left[{ }^{3} \mathrm{H}\right]$ 17a-hydroxyprogesterone as a precursor. Steroid metabolites were extracted from incubated media and oocytes. The extracts were separated and identified using thin layer chromatography, high performance liquid chromatography and gas chromatography-mass spectrometry. The identified metabolites were androstenedione $\left(A_{4}\right)$, testosterone $(T)$ and estrone $\left(E_{1}\right)$. The metabolites of $A_{4}$ was dominant in all size of oocytes and it was the highest in $480 \mu \mathrm{m}$ diameter oocytes. The metabolites of two progestins, 17a,20ß-dihydroxy-4pregnen-3-one and 17a,20a-dihydroxy-4-pregnen-3-one were detected in the oocytes less than $480 \mu \mathrm{m}$ diameter although they were not identified definitely. In the oocytes of $480 \mu \mathrm{m}$ diameter, metabolite of progestin was the highest, and germinal vesicle (GV) was still in the middle of cytoplasm. In the oocytes of $500 \mu \mathrm{m}$ diameter, GV was began to migrate and the major metabolites were $A_{4}$ and $E_{1}$. The metabolite of $E_{1}$ was detected in all size of oocytes and it was higher than that of $E_{2}$. These results suggest that oocytes of $480 \mu \mathrm{m}$ diameter are the transitional stage involving steroidogenic shift to final oocyte maturation and potential function of $E_{1}$ during maturation process.

Keywords: Red spotted grouper, Steroid metabolite, Oocyte, Maturation

\section{INTRODUCTION}

Oocyte maturation process in teleosts is under the control or feedback of sex steroids, synthesized from the follicle cell, and they are regulated by the hypothalamus-pituitary -gonad axis (Nagahama \& Yamashita, 2008; Planas \& Swanson, 2008). In female fish, it is well known that estradiol-17 $\beta$ $\left(\mathrm{E}_{2}\right)$ is the major sex steroid, and transported to liver during vitellogenesis, the period of vitellogenin production in liver. Subsequently, progestins function as such as maturation inducing steroid (MIS), $17 \alpha, 20 \beta$-dihydroxy-4-pregnen-3-one (17 $\alpha 20 \beta$ P) and/or $17 \alpha, 20 \beta$,21-trihydroxy-4-pregnen3-one (17 $\alpha 20 \beta$ 21P) induce final oocyte maturation, i.e., germinal vesicle breakdown (GVBD) and ovulation (Patiño \& Sullivan, 2002; Baek, 2008; Nagahama \& Yamashita, 2008). Although the actions and role of these sex steroids had been studied in many fish species, the profiling of various sex steroids in fish reproduction is still insufficient because of not only diverse fish species but their diverse 
Ethics approval

This article does not require IRB/IACUC approval because there are no human and animal participants. reproductive characteristics (Frisch A, 2004; Tokarz et al., 2015).

The red-spotted grouper, Epinephelus akaara is a marine multiple spawner and protogynous, as a Serranid fish distributed mainly in Korea, southern Japan, southern China and East China Sea (Craig et al., 2011; Lee et al., 2020). This species is economically important in aquaculture industry and it is interested in artificial control of its reproduction such as induction of maturation and masculinization ( $\mathrm{Li}$ et al., 2006; Lee et al., 2014; Oh et al., 2018; Lee et al., 2020). However, there is little information about sex steroid synthesis related to oocyte maturation of this species. In the present study, we investigated the in vitro profiling of sex steroid metabolites from ovarian follicles of red spotted grouper.

\section{MATERIALS AND METHODS}

\section{Chemicals}

Authentic steroids were purchased from Sigma-Aldrich (St. Louis, MO, USA) or Steraloids (Wilton, $\mathrm{NH}, \mathrm{USA}$ ). Mother solutions $(\mathrm{mg} / \mathrm{mL}$ ) were prepared by dissolving the authentic steroids in pure ethanol. These were further diluted in incubation media. The ethanol concentration in the incubation medium was maintained at less than $0.1 \%$. Radioactive $\left[{ }^{3} \mathrm{H}\right]-17 \alpha$-hydroxyprogesterone $\left(\left[{ }^{3} \mathrm{H}\right]-17 \alpha \mathrm{P}\right)$ was obtained from Amersham Life Science (London, UK).

\section{Preparation of oocytes for incubation}

The experimental fish were reared and adjusted to $14 \mathrm{~L}: 10 \mathrm{D}$ and $25^{\circ} \mathrm{C}$ in recirculating aquaria (500 L) from Marine Science Institute, Jeju National University, Korea. Oocytes were obtained by cannulation after anesthetization of eight mature females. The cannulated oocytes were put into cold balanced salt solution (BSS; $132.96 \mathrm{mM} \mathrm{NaCl}, 3.09 \mathrm{mM} \mathrm{KCl}, 0.28 \mathrm{mM} \mathrm{MgSO}_{4} .7 \mathrm{H}_{2} \mathrm{O}, 0.98$ $\mathrm{mM} \mathrm{MgCl} 2.6 \mathrm{H}_{2} \mathrm{O}, 3.40 \mathrm{mM} \mathrm{CaCl}_{2} \cdot 6 \mathrm{H}_{2} \mathrm{O}, 3.65 \mathrm{mM}$ HEPES). Oocytes were separated into groups with the largest diameter using fine forceps from each mature fish. Oocytes with average diameters of 350, 400, 420, 440, 480, and $500 \mu \mathrm{m}$ were used for the in vitro incubation. Thirty follicle-enclosed oocytes were incubated in each well of triplicates.

We incubated isolated oocytes in $1 \mathrm{~mL}$ of Leibovitz L15 medium (Gibco, Grand Island, NY, USA) with $55 \mathrm{kBq}\left[{ }^{3} \mathrm{H}\right]-17 \alpha \mathrm{P}$ a radiolabeled precursor for separation of metabolites. The $\mathrm{pH}$ and osmolality of the media were adjusted to 7.7 and $360 \mathrm{mOsm}$, respectively. The plates were incubated for $24 \mathrm{~h}$ at $18^{\circ} \mathrm{C}$.

Some ovarian fragment from each fish were fixed, washed, dehydrated and paraffin-embedded. Sections of 4-5 $\mu \mathrm{m}$ were HE stained and observed through a light microscope.

\section{Analysis of steroid metabolism}

At the end of the incubation, steroids extraction, separation and identification of metabolites were followed by our previous studies (Hwang et al., 2012; Baek et al., 2013; Lee \& Baek, 2015). Steroid metabolites produced from $\left[{ }^{3} \mathrm{H}\right]-17 \alpha \mathrm{P}$ were compared with the values were expressed as photo-stimulated luminescence (PSL) - background (BG) per $\mathrm{mm}^{2}$ of each fraction area from autoradiography.

\section{RESULTS}

\section{Oocyte developmental stage}

In histological observation of each diameter of oocytes, oocytes of 350-480 $\mu \mathrm{m}$ diameter were 
vitellogenic stage; yolk granules were spread throughout the cytoplasm and oil droplets (Od) were accumulated near the nucleus $(\mathrm{N})$ as oocyte diameter increased (Fig. 1A-E). In particular, nucleus was observed in the middle of cytoplasm in these size of oocytes. In the oocytes of $500 \mu \mathrm{m}$ diameter, migration of $\mathrm{N}$ was observed and many Ods were observed near migrating $\mathrm{N}$ (Fig. 1F).

\section{Identification of steroid metabolites}

After incubation of oocytes with $\left[{ }^{3} \mathrm{H}\right]-17 \alpha \mathrm{P}, 7$ major fractions appeared on thin layer chromatography (TLC). Fraction 1, 2, 4, 5, and 6 were as the same retention factor (RF) of standard estrone $\left(\mathrm{E}_{1}\right)$, androstenedione $\left(\mathrm{A}_{4}\right), 17 \alpha \mathrm{P}, \mathrm{T}$, and $17 \alpha 20 \beta \mathrm{P}$, respectively (Fig. 2). Fraction 3 and 7 were overlapped with $\mathrm{E}_{2}+$ unknown metabolite and $17 \alpha, 20 \alpha$-dihydroxy-4-pregnen-3one $(17 \alpha 20 \alpha \mathrm{P})$ +unknown metabolite, respectively. Among these 7 metabolites, fraction 1, 2 , and 5 were identified as $\mathrm{E}_{1}, \mathrm{~A}_{4}$, and $\mathrm{T}$ through further analysis with high performance liquid chromatography and GC/MS (Fig. 3). The other metabolites were not identified due to their low measured activities.

\section{Metabolites profiling during maturation process}

We compared each metabolite with PSL value from TLC autoradiography followed each oocyte diameter for steroid metabolites profiling during oocyte maturation (Fig. 4). The $\mathrm{A}_{4}$ metabolite was dominant [15.47-92.41 (PSL-BG)/mm $\left.{ }^{2}\right]$ in all size of oocytes and it was the highest in 480 $\mu \mathrm{m}$ diameter oocytes. T metabolite increased gradually $\left[4.55-13.76\right.$ (PSL-BG) $\left./ \mathrm{mm}^{2}\right]$ as oocyte diameter increased although it was not detected at 350 and $500 \mu \mathrm{m}$ diameter oocytes in the autoradiography. $\mathrm{E}_{2}$ overlapped with unknown metabolite was detected only in $350 \mu \mathrm{m}$ diameter oocytes [4.27 (PSL-BG)/mm²]. $\mathrm{E}_{1}$ metabolite [3.08-9.24 (PSL-BG) $\left./ \mathrm{mm}^{2}\right]$ was detected in all size of oocytes and it was the highest in $420 \mu \mathrm{m}$ diameter oocytes. $17 \alpha 20 \beta \mathrm{P}$ metabolite was detected in 350-420 $\mu \mathrm{m}$ diameter oocytes [2.27-4.64 (PSL-BG)/mm $\left.{ }^{2}\right] .17 \alpha 20 \alpha \mathrm{P}$ overlapped with unknown metabolite was detected 350,420-480 $\mu$ m diameter oocytes [3.37-10.82 (PSL-BG)/

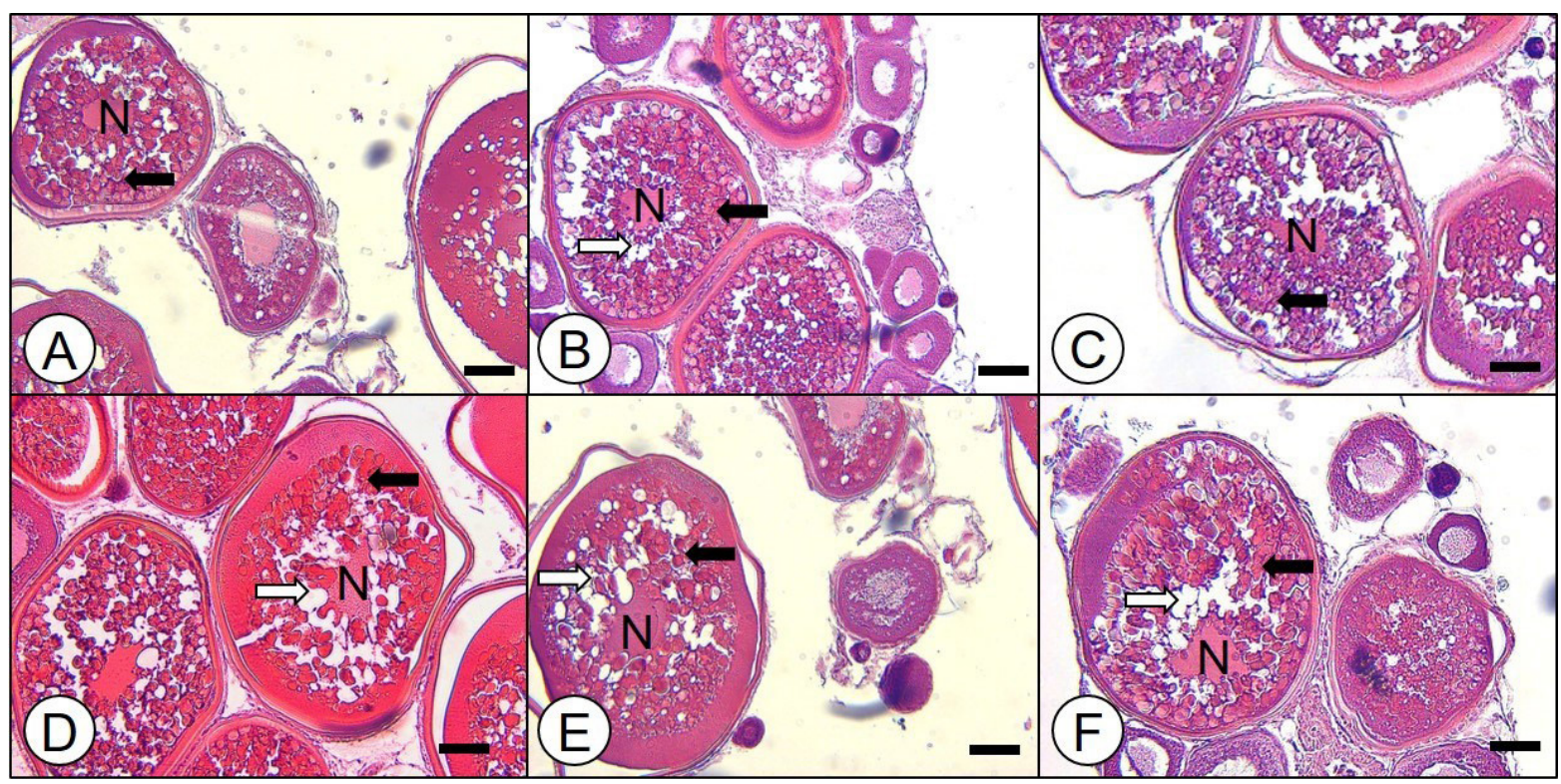

Fig. 1. Histological observation of ovarian fragment from mature red spotted grouper. (A) oocytes of $350 \mu \mathrm{m}$, (B) oocytes of $400 \mu \mathrm{m}$, (C) oocytes of 420 $\mu \mathrm{m},(D)$ oocytes of $440 \mu \mathrm{m},(E)$ oocytes of $480 \mu \mathrm{m},(F)$ oocytes of $500 \mu \mathrm{m}$. Scale bars=100 $\mu \mathrm{m}$, stained with H-E. N, nucleus; blank arrow, oil droplet; solid arrow, yolk granule. 


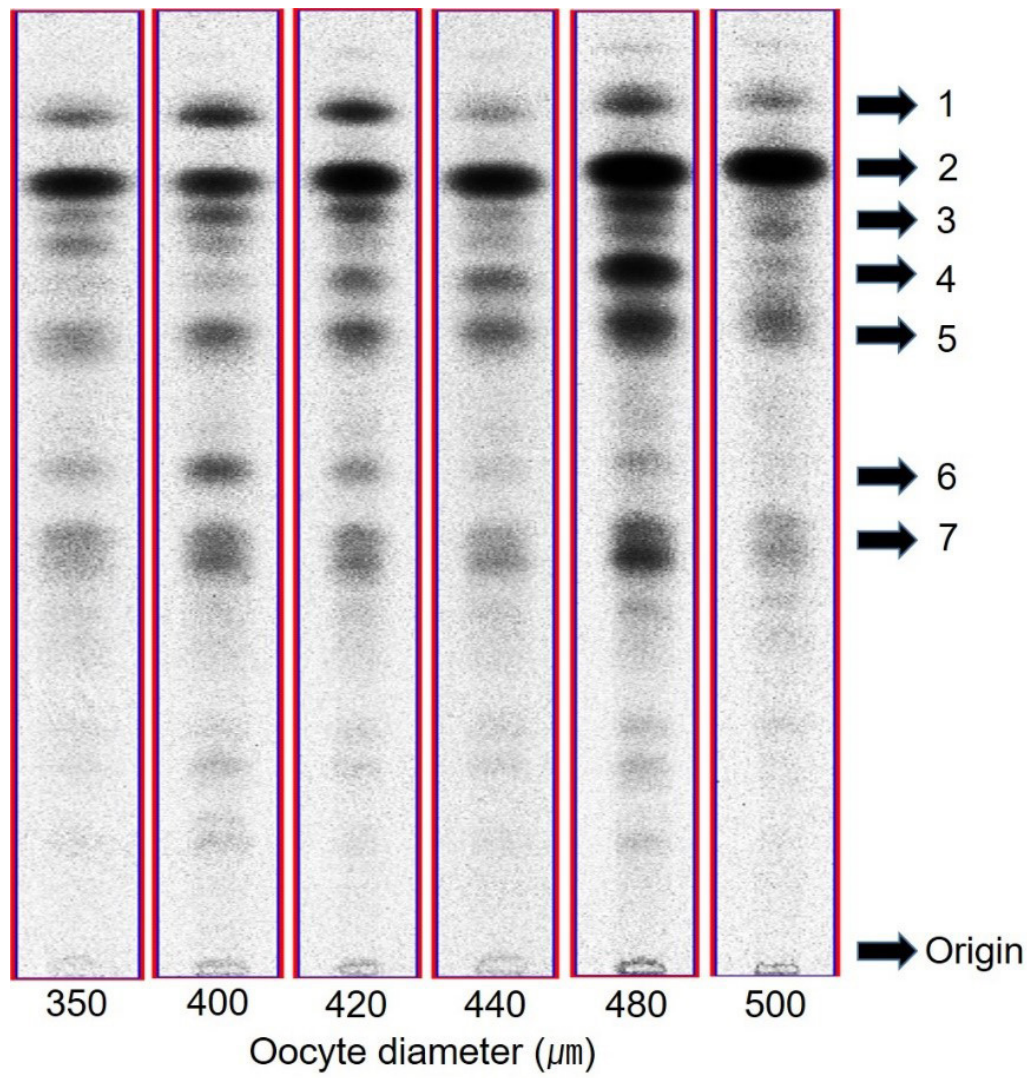

Fig. 2. Autoradiograms of steroid metabolites produced from $\left[{ }^{3} \mathrm{H}\right] 17 \alpha$-hydroxyprogesterone after $24 \mathrm{~h}$ incubation with isolated oocytes from red spotted grouper. Steroid metabolites from radiolabeled precursor were separated by thin layer chromatography developed with a benzene:acetone $(4: 1)$ and benzene:ethyl acetate $(4: 1)$ solvent system. 1 , estrone $\left(E_{1}\right) ; 2$, androstenedione $\left(A_{4}\right)$; 3 , estradiol-17 $\beta$

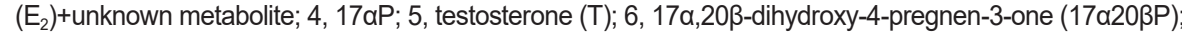
7, 17a,20a-dihydroxy-4-pregnen-3-one (17a20aP)+unknown metabolite.

$\left.\mathrm{mm}^{2}\right]$ with the highest in $480 \mu \mathrm{m}$ diameter oocytes. $17 \alpha 20 \alpha \mathrm{P}$ or $17 \alpha 20 \beta \mathrm{P}$ metabolite was not detected in $500 \mu \mathrm{m}$ diameter oocytes.

\section{DISCUSSION}

In general, $\mathrm{E}_{2}$, the principle estrogen is dominant in the early stage of maturation, i.e. oocyte growing and MIS such as $17 \alpha 20 \beta \mathrm{P}$ or $17 \alpha 20 \beta 21 \mathrm{P}$ dominant in the late stage of maturation, i.e. GVBD and ovulation (Tokarz et al., 2015). In histological observation of oocytes, 350-480 $\mu \mathrm{m}$ diameter oocytes were vitellogenic stage and $500 \mu \mathrm{m}$ diameter oocytes were final maturation stage with migration of germinal vesicle (GV). We consider the $480 \mu \mathrm{m}$ diameter oocytes would be fully vitellogenic stage; GV was still in the middle of cytoplasm and prior to GVM stage.

We identified the major steroid metabolites and investigate their profiling from vitellognic to germinal vesicle migration oocytes of red spotted grouper. The major metabolites synthesized from the oocytes were $\mathrm{A}_{4}, \mathrm{E}_{1}, \mathrm{~T}, \mathrm{E}_{2}$ and two progestins. Among these metabolites, $\mathrm{A}_{4}, \mathrm{E}_{1}$, and $\mathrm{T}$ were identified through GC/MS, but the others were not identified due to their low activities. Although we could not identify 2 progestins, progestin 1 and 2 co-migrated with $17 \alpha 20 \alpha \mathrm{P}$ and $17 \alpha 20 \beta \mathrm{P}$ in TLC system. To date, MIS of groupers had not been identified yet although $17 \alpha 20 \beta \mathrm{P}$ 

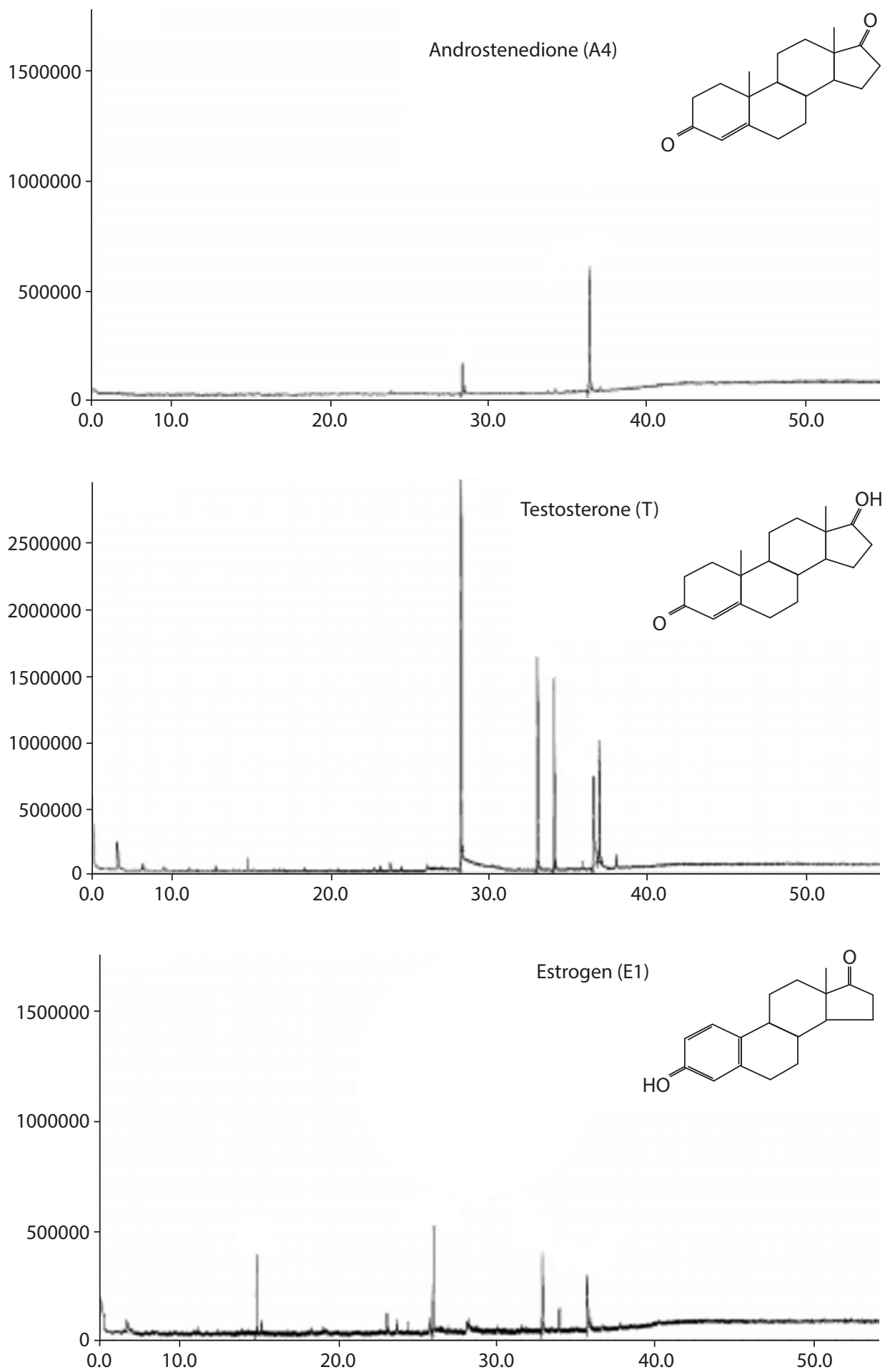

Fig. 3. Mass spectra of steroid metabolites identified as androstenedione, testosterone and estrone from oocytes of red spotted grouper.

is well-known MIS in many fish species and was measured from plasma of Epinephelus morio (Johnson et al., 1998; Shein et al., 2004; Nagahama \& Yamashita, 2008). Interestingly, progestin 1 metabolite, suspected $17 \alpha 20 \alpha \mathrm{P}$ increased gradually in 420-480 $\mu \mathrm{m}$ diameter oocytes. Previous studies reported that $17 \alpha 20 \alpha \mathrm{P}$ may act as a MIS of flatfish, Limanda limanda, Verasper variegates 


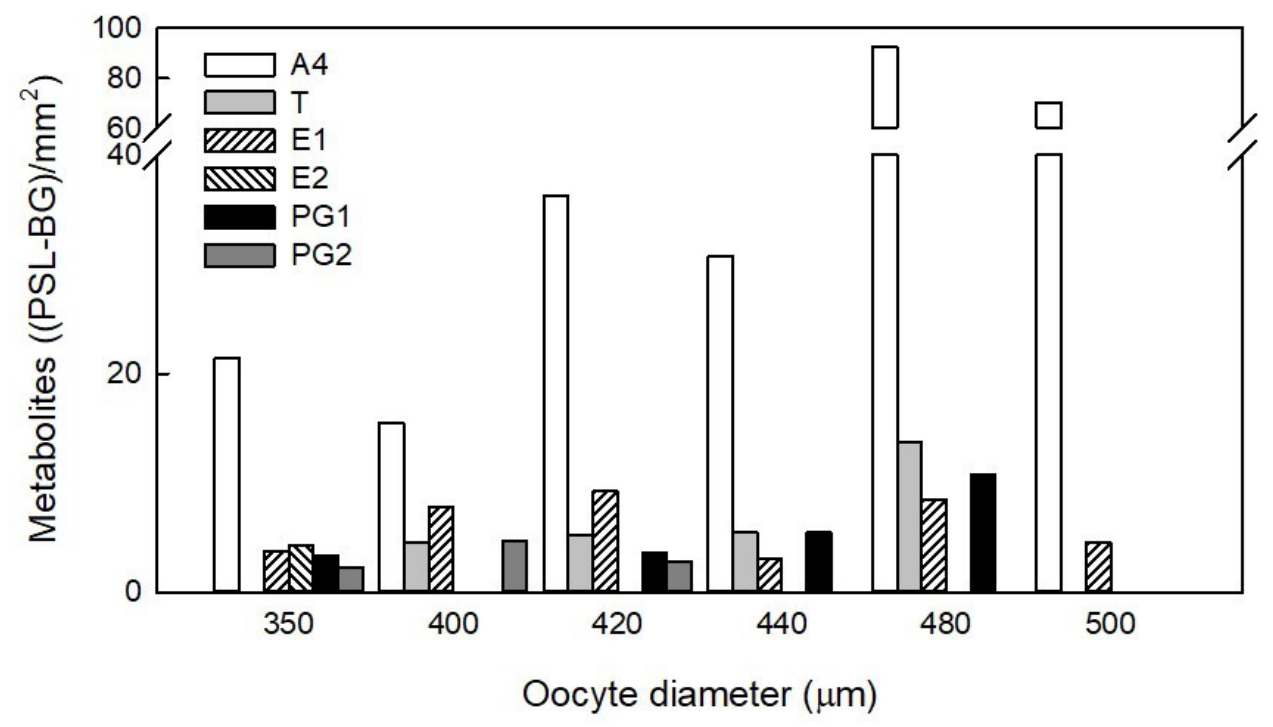

Fig. 4. Steroid metabolites from radioactive precursor during oocyte maturation. The values indicate digital photo-luminescence (PSL) by autoradiography and were expressed as PSL-backgroud (BG) per $\mathrm{mm}^{2}$ of each fraction area. A4, androstenedione; T, testosterone; E1, estrone; E2, estradiol-17ß; PG1, 17a,20a-dihydroxy-4-pregnen-3-one; PG2, 17a,20ß-dihydroxy-4-pregnen-3-one.

and gobiid fish, Chasmichthys dolichognathus (Canario \& Scott, 1990; Baek, 2001, 2008). In this regard, $17 \alpha 20 \alpha$ P metabolite would be related to maturation process with its increase until fully vitellogenic stage and then decrease at GVM stage although its role is not clear. Further study that identification of MIS and it's maturation inducing capacity should be conducted.

Among the metabolites, $\mathrm{A}_{4}$ was predominant in all size of oocytes even in the GVM stage (500 $\mu \mathrm{m}$ oocyte diameter). In our previous study, $\mathrm{A}_{4}$ was also produced dominantly in vitellogenic oocytes from red lip mullet, Chelon baematocheilus, blacktip grouper, Epinephelus fasciatus, and blackfin flounder, Glyptocephalus stelleri (Baek et al., 2011; Hwang et al., 2012; Lee \& Baek, 2015). A few studies reported that $\mathrm{A}_{4}$ is related to sex change in protogynous hermaphrodite, Monopterus albus and Sparisoma viride (Yeung \& Chan, 1987; Cardwell \& Liley, 1991; Yeung et al., 1993). Moreover, Montero et al. (1995) reported that androgen could act as a substrate for estrogen production in vitellogenesis of European eel, Anguilla anguilla. In the present study, we suspect that $\mathrm{A}_{4}$ may regulate oocyte maturation process rather than sex change of red spotted grouper since there was no testicular tissue in gonad and it's the highest value with progestin production at 480 $\mu \mathrm{m}$ diameter oocytes, the transitional stage into final maturation.

We demonstrated that $\mathrm{E}_{1}$ metabolite was also detected in all size of oocytes and its detected value was higher than that of $\mathrm{E}_{2}$ metabolite. In a majority of fishes, it is well known that $\mathrm{E}_{2}$ is converted from T by aromatase (Fukada et al., 1996; Chang et al., 1997; Aggarwal et al., 2014). However, $\mathrm{E}_{1}$ may have a minor vitellogenic role in some species (Specker \& Sullivan, 1994; Routledge et al., 1998) and act as a precursor of $\mathrm{E}_{2}$ synthesis (Kazeto et al., 2000; Ohta et al., 2001; Ohta et al., 2002; Mindnich et al., 2004; Zhou et al., 2005). Our results also suggest that $\mathrm{E}_{1}$ may regulate vitellogenesis with $\mathrm{E}_{2}$ and also has a certain role in oocyte maturation process despite insufficient data. Future study such as exogenous $\mathrm{E}_{1}$ treatment on oocyte maturation would provide more definite information about steroidogenic profiling. In conclusion, the present study provides in vitro steroid metabolites profiling that identification of major metabolites and its's changes during oocytes maturation of red spotted grouper. We also suggest that $17 \alpha 20 \beta \mathrm{P}$ and/or $17 \alpha 20 \alpha \mathrm{P}$ may act as a MIS and the potential role of $E_{1}$ in maturation process. 


\section{REFERENCES}

Aggarwal N, Goswami SV, Khandelwal P, Sehgal N (2014) Aromatase activity in brain and ovary: Seasonal variations correlated with circannual gonadal cycle in the catfish, Heteropneustes fossilis. Indian J Exp Biol 52:527-537.

Baek HJ (2001) Biosynthesis of $17 \alpha$-hydroxy, $20 \alpha$-dihydroprogesterone by ovaries of the spotted flounder (Verasper variegatus).J Fish Sci Technol 4:70-74.

Baek HJ (2008) Production of C21 steroids in longchin goby, Chasmichthys dolichognathus during oocyte maturation. Dev Reprod 12:107-112.

Baek HJ, Hwang IJ, Lee YD, Kim HB (2011) Effects of nonylphenol and $3,3^{\prime}, 4,4^{\prime}, 5$-pentachlorobiphenyl on in vitro oocyte steroidogenesis in redlip mullet, Chelon haematocheilus. Anim Cells Syst 15:189-196.

Baek HJ, Kim DG, Kim HB (2013) In vitro steroidogenesis on oocyte development in the starry flounder, Platichthys stellatus. Dev Reprod 17:421-426.

Canario AVM, Scott AP (1990) Effects of steroids and human chorionic gonadotrophin on in vitro oocyte final maturation in two marine flatfish: The dab, Limanda limanda, and the plaice, Pleuronectes platessa. Gen Comp Endocrinol 77:161-176.

Canario AVM, Scott AP (1990) Plasma levels of ovarian steroids, including $17 \alpha-20 \alpha-$ dihydroxy-4-pregnen-3-one and $3 \beta, 17 \alpha, 20 \alpha$-trihydroxy-5 $\beta$-pregnane, in female dabs (Limanda limanda) — marine flatfish—induced to mature and ovulate with human chorionic gonadotrophin. Gen Comp Endocrinol 77:177-191.

Cardwell JR, Liley NR (1991) Hormonal control of sex and color change in the stoplight parrotfish, Sparisoma viride. Gen Comp Endocrinol 81:7-20.

Chang XT, Kobayashi T, Kajiura H, Nakamura M, Nagahama Y (1997) Isolation and characterization of the cDNA encoding the tilapia (Oreochromis niloticus) cytochrome P450 aromatase (P450arom): Changes in P450arom mRNA, protein and enzyme activity in ovarian follicles during oogenesis.J Mol Endocrinol 18:57-66.

Craig MT, Sadovy de Mitcheson YJ, Heemstra PC (2011) Groupers of the World: A Field and Market Guide. National Inquiry Services Center [NISC], Grahamstown, South Africa.

Frisch A (2004) Sex-change and gonadal steroids in sequentially-hermaphroditic teleost fish. Rev Fish Biol Fish 14:481-499.

Fukada S, Tanaka M, Matsuyama M, Kobayashi D, Nagahama Y (1996) Isolation, characterization, and expression of cDNAs encoding the medaka (Oryzias latipes) ovarian follicle cytochrome P-450 aromatase. Mol Reprod Dev 45:285-290.

Hwang IJ, Kim SK, Choi SJ, Lee CH, Lee YD, Kim HB, Baek HJ (2012) Effects of steroid hormones on in vitro GVBD and oocyte steroidogenesis in blacktip grouper, Epinephelus fasciatus. Dev Reprod 16:39-45.

Johnson K, Thomas P, Wilson RR (1998) Seasonal cycles of gonadal development and plasma sex steroid levels in Epinephelus morio, a protogynous grouper in the eastern Gulf of Mexico.J Fish Biol 52:502-518.

Kazeto Y, Ijiri S, Matsubara H, Adachi S, Yamauchi K (2000) Cloning of $17 \beta$-hydroxysteroid dehydrogenase-I cDNAs from Japanese eel ovary. Biochem Biophys Res Commun 279:451-456.

Lee CH, Hur SW, Kim BH, Soyano K, Lee YD (2020) Induced maturation and fertilized egg production of the red-spotted grouper, Epinephelus akaara, using adaptive physiology of photoperiod and water temperature. Aquac Res 51:2084-2090.

Lee CH, Hur SW, Na OS, Baek HJ, Noh CH, Han SH, Lee YD (2014) Induction of primary male in juvenile red spotted grouper Epinephelus akaara by immersion of $17 \alpha$-methyltestosterone. 
Dev Reprod 18:127-131.

Lee HW, Baek HJ (2015) Steroid metabolism in the blackfin flounder Glyptocephalus stelleri during oocyte maturation. Korean J Fish Aquat Sci 48:483-488.

Li GL, Liu XC, Lin HR (2006) Effects of aromatizable and nonaromatizable androgens on the sex inversion of red-spotted grouper (Epinephelus akaara). Fish Physiol Biochem 32:25-33.

Mindnich R, Deluca D, Adamski J (2004) Identification and characterization of $17 \beta$-hydroxysteroid dehydrogenases in the zebrafish, Danio rerio. Mol Cell Endocrinol 215:19-30.

Montero M, Le Belle N, King JA, Millar RP, Dufour S (1995) Differential regulation of the two forms of gonadotropin-releasing hormone ( $\mathrm{mGnRH}$ and $\mathrm{cGnRH}-\mathrm{II})$ by sex steroids in the European female silver eel (Anguilla anguilla). Neuroendocrinology 61:525-535.

Nagahama Y, Yamashita M (2008) Regulation of oocyte maturation in fish. Dev Growth Differ 50:S195-S219.

Oh SB, Lee CH, Lee YD (2018) Induction of puberty in red spotted grouper, Epinephelus akaara by water temperature.J Aquac Res Dev 9:1000537.

Ohta K, Mine T, Yamaguchi A, Matsuyama M (2001) Steroidogenic pathway to estradiol-17 $\beta$ synthesis in the ovarian follicles of the protogynous wrasse, Pseudolabrus sieboldi. Zool Sci 18:937-945.

Ohta K, Yamaguchi S, Yamaguchi A, Okuzawa K, Kagawa H, Matsuyama M (2002) Biosynthesis of estradiol-17 $\beta$ in the ovarian follicles of the red seabream Pagrus major during vitellogenesis. Fish Sci 68:680-687.

Patiño R, Sullivan CV (2002) Ovarian follicle growth, maturation, and ovulation in teleost fish. Fish Physiol Biochem 26:57-70.

Planas JV, Swanson P (2008) Physiological function of gonadotropins in fish. In: Rocha MJ, Arukwe A, Kapoor BG (eds), Fish Reproduction. Science Publishers, Enfield, NH, pp 37-66.

Routledge EJ, Sheahan D, Desbrow C, Brighty GC, Waldock M, Sumpter JP (1998) Identification of estrogenic chemicals in STW effluent. 2. In vivo responses in trout and roach. Environ Sci Technol 32:1559-1565.

Shein NL, Chuda H, Arakawa T, Mizuno K, Soyano K (2004) Ovarian development and final oocyte maturation in cultured sevenband grouper Epinephelus septemfasciatus. Fish Sci 70:360-365.

Specker JL, Sullivan CV (1994) Vitellogenesis in fishes: Status and perspectives. In: Davey KG, Peter RE, Tobe SS (eds), Perspectives in Comparative Endocrinology. National Research Council of Canada, Ottawa, ON, pp 304-315.

Tokarz J, Möller G, Hrabě de Angelis M, Adamski J (2015) Steroids in teleost fishes: A functional point of view. Steroids 103:123-144.

Yeung WSB, Chan STH (1987) The plasma sex steroid profiles in the freshwater, sex-reversing teleost fish, Monopterus albus (Zuiew). Gen Comp Endocrinol 65:233-242.

Yeung WSB, Chen H, Chan STH (1993) The in vitro metabolism of radioactive androstenedione and testosterone by the gonads of the protogynous Monopterus albus at different sexual phases: A time-course and seasonal study. Gen Comp Endocrinol 89:313-322.

Zhou LY, Wang DS, Senthilkumaran B, Yoshikuni M, Shibata Y, Kobayashi T, Sudhakumari CC, Nagahama Y (2005) Cloning, expression and characterization of three types of $17 \beta$-hydroxysteroid dehydrogenases from the Nile tilapia, Oreochromis niloticus. J Mol Endocrinol 35:103-116. 